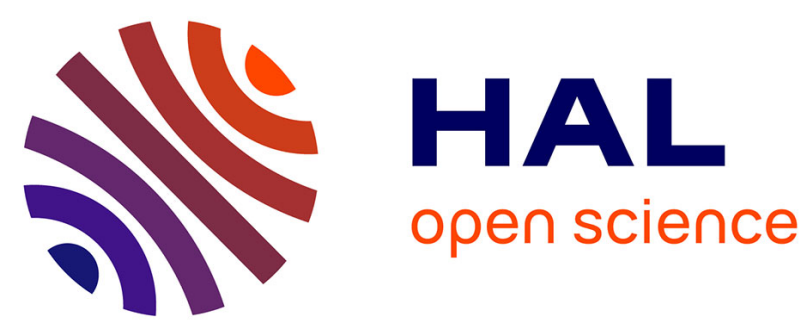

\title{
DETERMINANTS OF SELF-HANDICAPPING STRATEGIES IN SPORT AND THEIR EFFECTS ON ATHLETIC PERFORMANCE
}

Guillaume R. Coudevylle, Kathleen Martin Ginis, Jean-Pierre Famose

\section{- To cite this version:}

Guillaume R. Coudevylle, Kathleen Martin Ginis, Jean-Pierre Famose. DETERMINANTS OF SELFHANDICAPPING STRATEGIES IN SPORT AND THEIR EFFECTS ON ATHLETIC PERFORMANCE. Social behavior and personality, 2008, 36 (3), pp.391-398. 10.2224/sbp.2008.36.3.391 . hal-01343254

\section{HAL Id: hal-01343254 \\ https://hal.univ-antilles.fr/hal-01343254}

Submitted on 9 Jan 2018

HAL is a multi-disciplinary open access archive for the deposit and dissemination of scientific research documents, whether they are published or not. The documents may come from teaching and research institutions in France or abroad, or from public or private research centers.
L'archive ouverte pluridisciplinaire HAL, est destinée au dépôt et à la diffusion de documents scientifiques de niveau recherche, publiés ou non, émanant des établissements d'enseignement et de recherche français ou étrangers, des laboratoires publics ou privés. 


\section{Abstract}

2 The purpose of the present experiment was to examine self-efficacy and self-esteem as predictors

3 of claimed and behavioral self-handicapping and to compare the relationship between behavioral

4 and claimed self-handicaps, and athletic performance. A total of 31 basketball players

5 participated in the study. Claimed self-handicaps were significantly negatively correlated with

6 self-esteem whereas behavioral self-handicapping was significantly negatively correlated with

7 self-efficacy. Performance was negatively correlated with behavioral self-handicapping, but was

8 not correlated with claimed self-handicapping. These findings reinforce the conceptual distinction

9 between claimed and behavioral self-handicaps by demonstrating that the two strategies are

10 indeed related to different factors and that they have different consequences for performance.

11

12 Key words: self-handicapping, self-esteem, self-confidence, performance, sport 
Determinants of Self-handicapping Strategies in Sport and their Effects on Athletic Performance Self-handicapping is a self-presentational strategy whereby people make claims or engage in behaviors prior to an upcoming performance, in order to have a reasonable excuse for a possible failure (Berglas \& Jones, 1978). From an attributional perspective, self-handicaps blur the relationship between ability and performance. Thus, a self-handicapping athlete who performs poorly can attribute failure to the performance impediment rather than ability or competence whereas the athlete who performs well creates the impression of being especially competent and talented, because success was achieved despite impediments (Tice, 1991).

Theorists have highlighted the important conceptual distinction between behavioral and claimed self-handicapping (e.g., Hirt, Deppe, \& Gordon, 1991; Leary \& Shepperd, 1986). However, effort has not been directed toward determining whether each has different determinants. The majority of the published sport studies have focused on determinants of claimed self-handicapping (e.g., Kuczka \& Treasure, 2005; Martin \& Brawley, 2002) or on determinants behavioral self-handicapping (e.g., Berglas \& Jones, 1978; Pyszczynski \& Greenberg, 1983). The few studies that have examined both types have assumed common determinants (e.g., Elliot, Cury, Fryer, \& Huguet, 2006; Thompson \& Richardson, 2001). Behavioral self-handicaps are a more costly, riskier strategy than claimed self-handicaps. For example, not practicing can provide an excuse for poor performance, but also decreases the likelihood of a successful performance. In contrast, simply claiming to be too anxious or tired also serves as an excuse for poor performance, but does not actually reduce the likelihood of success (see Hirt et al., 1991). Given these differences, it is possible that different factors underlie the use of these two strategies (see Coudevylle, Famose, Martin Ginis, \& Gernigon, 2007). Knowledge of these factors would contribute to a better understanding of predictors of selfhandicapping and the development of interventions to alter the use of self-handicaps. 
Athletes who use behavioral self-handicaps may take such a risk because they are convinced of an impending performance failure. In line with this reasoning, Pyszczynski and Greenberg (1983) showed that participants in a low-probability of success condition intended to exert less effort on an upcoming highly ego-relevant task, than did participants in a highprobability of success condition. As social cognitive theory proposes that maladaptive behaviors--such as reduced effort--result primarily from low expectations of mastery in an uncertain situation (Bandura, 1986, 1997), it is plausible that the use of behavioral self-handicaps may be linked to situation-specific low levels of performance self-efficacy.

In contrast, athletes who use claimed self-handicaps may suffer from more general selfdoubts; they may not necessarily believe that failure is imminent, but they may have weak beliefs about their general levels of capability, success and self-worth. Within the self-handicapping literature, feeble self-beliefs have been conceptualised as low self-esteem (see Tice, 1991). Athletes with low self-esteem may not want to risk sabotaging an upcoming performance with a costly behavioral self-handicap, but just in case they do fail, they may desire the protection of a relatively low-risk, claimed self-handicap. Indeed, Martin and Brawley (2002, Study 2) found that low self-esteem was associated with greater claimed self-handicapping prior to a fitness test. The primary purpose of the present experiment was to examine self-efficacy and selfesteem as predictors of claimed and behavioral self-handicapping. It was predicted that selfefficacy would be negatively correlated with the use of a behavioral self-handicap whereas selfesteem would be negatively correlated with the use of claimed self-handicaps. A secondary purpose was to compare the relationship between behavioral and claimed self-handicaps, and athletic performance. Presumably, behavioral self-handicaps would have a negative effect on performance because they lower one's chance of success (Hirt et al., 1991; Leary \& Shepperd, 1986). Indeed, reduced preparatory effort (i.e., a behavioral self-handicap) has been linked with 
1 poorer performance (e.g., Elliot et al., 2006). In contrast, claimed self-handicaps may improve

2 performance by reducing pressure to perform well (Leary \& Shepperd, 1986; Ryska, Yin, \&

3 Cooley, 1998). Two studies involving children produced conflicting results regarding the effects

4 of claimed handicaps on performance (Elliot et al., 2006; Ryska, 2002). Thus, further research is

5 warranted to address this issue. We hypothesized that performance on a basketball task would be

6 negatively related to behavioral self-handicapping and positively related to claimed self-

7 handicapping.

Method

\section{Participants}

$114.8)$ and 15 women $(M$ age $=19.6$ years; $S D=3.9)$. All players competed at the French regional

12 level - a sufficiently competitive level to ensure that participants would be personally invested in

13 the experimental task and its outcome.

\section{Measures}

15 General Self-esteem was measured by the French version (Vallières \& Vallerand, 1990) of

16 Rosenberg's Self-Esteem Scale (Rosenberg, 1965). Participants rated the 10 scale items on a

17 four-point Likert scale $(1=$ strongly disagree; 4 = strongly agree $)$.

18 Self-efficacy was measured using a procedure adapted from Bandura and Adams (1977).

19 Participants indicated if they believed that they could make 1, 2, 3, 4, and 5 successful passes

20 through the obstacle course (yes/no response) and if so, their degree of confidence $(0 \%=n o t$

21 sure; $100 \%=$ totally sure). A mean score was calculated across the items to which participants

22 responded 'yes'.

23 Claimed Self-handicapping was measured using a state measure similar to that used and validated 24 by Martin and Brawley (2002, Study 2). The scale consisted of 14 impediments that athletes may 
use as self-handicaps such as: "I am feeling tired," "I have personal concerns in this moment," and "I am ill." The impediments were those most frequently cited by athletes in studies of selfhandicapping in sport (e.g., Carron, Prapavessis, \& Grove, 1994). Participants indicated whether each impediment was present (yes/no), and the extent to which it would interfere with their performance (i.e., perceived impact), using a scale ranging from 0 (not at all) to 6 (extremely). A total score was calculated by summing the impact scores for the impediments that were present. Two items were reversed scored before being added to the total.

Behavioral Self-handicapping. Within the context of sports participation, a lack of preparatory effort constitutes an index of behavioral self-handicapping (Prapavessis, Grove, \& Eklund, 2004). Thus, behavioral self-handicapping was operationalized as the amount of time, in minutes, spent practicing during a warm-up period. A measurement protocol used by Harris and Snyder (1986) and Tice (1991) was employed (see procedure).

Performance. Performance was scored by counting the number of successful shots and passes completed on an obstacle course (described next). Performance scores could range from 0 to 11 . The Experimental Task

The task consisted of completing three repetitions of an obstacle course laid out on a standard basketball court. The test began with the completion of two free-throws followed by running to mid-court, and then turning around backwards and performing a backward defensive shuffle to the end of the court. Then, the participant picked up a basketball and dribbled it to midcourt. At mid-court, the participant dribbled the ball between three pylons while bouncing the ball between the legs and passing it behind the back. The participant then continued to the basket and attempted a lay-up. After the lay-up, the participant repeated the entire course again and finished with a jump shot. The course was repeated a third time, finishing with a three-point shot. Procedure 
To maximize the likelihood of self-handicapping, an experimental situation was created in

2

which factors that are known to elicit self-handicapping (for a review, see Coudevylle et al., 2008) were made salient. Specifically, the testing situation emphasized public performance, an emphasis on results, social comparisons of one's performance with others, and public awareness of the use of self-handicaps. Participants performed the test in the presence of spectators, coaches and other players, were told that their test results would be used to identify the best and worst players in the region, and that their scores would be compared with their teammates' scores. After hearing and reading this information, participants completed the measures of selfesteem and self-efficacy. Then, they completed the measure of claimed self-handicapping. In order to mask the true purpose of the self-handicapping questionnaire, participants were told: "The following questionnaire is intended to know your general actual state in order to comment on your results today. It will allow those that will evaluate your competence (the experimenter, your trainer, the other players, the spectators) to consider your current personal situation when authenticating your results and comparing them with those of the other participants. Your responses to this questionnaire will be made public along with your results so that those who evaluate your performance will be better able to evaluate your competence". After completing the claimed self-handicapping measure, the experimenter explained the warm-up procedure. In accordance with Harris and Snyder (1986) and Tice (1991), participants were told that they could have as much time as they desired to warm-up. To make sure that all participants realized that a lack of preparatory effort could serve as a behavioral self-handicap, the experimenter told the participants that a lack of preparatory effort could provide an explanation for a good or bad performance on the test. He also reminded players that a good warm-up is essential to a good performance and that a bad warm-up can provoke a bad performance. Therefore, participants knew that the lack of practice before the test could be 
1 detrimental to their performance (see Harris \& Snyder, 1986; Tice, 1991). As no participant had

2 previously performed the experimental task, one can assume that a warm-up would be essential to 3 successful performance of the task.

4 Participants then warmed-up and the experimenter timed each participant's warm-up.

5 Once the participant indicated that she/he was ready, the experimental task proceeded. Upon

6 completion of the task, the participant was debriefed regarding the true purpose of the study.

Results

8

\section{Descriptive statistics}

Three female participants refused to perform the warm-up and test due to injury. Thus, for analyses relating to behavioral self-handicapping and performance, $n=28$. For all other analyses, $\mathrm{n}=31$. Prior to testing our hypotheses, ANOVAs were conducted to examine possible sex differences in self-handicapping (see Kuczka \& Treasure, 2005) and performance. As these ANOVAs were not significant ( $p s>.05)$, the data were collapsed across sex for all subsequent analyses.

\section{Correlation Analyses}

Table 1 shows that as predicted, claimed self-handicaps were significantly negatively correlated with self-esteem $(r=-.48, p<.01)$, but not self-efficacy $(r=-.12, p>.05)$, such that athletes with lower self-esteem reported a greater impact of performance impediments. Also as predicted, time spent warming up was significantly positively correlated with self-efficacy $(r=$ $.52, p<.01)$, but not self-esteem $(r=-.35, p>.05)$. Thus, as self-efficacy increased, behavioral self-handicapping decreased as indexed by greater time spent practicing. In partial support of our third hypothesis, performance was correlated with time spent warming up $(r=.50, p<.01)$, but not with the impact of claimed self-handicaps $(r=.07, p>.05)$. 


\section{Discussion}

The primary purpose of the present experiment was to examine self-efficacy and selfesteem as predictors of behavioral and claimed self-handicaps. The results supported the hypotheses and demonstrated that self-efficacy was negatively correlated with the use of a behavioral self-handicap (i.e., short time of preparation) whereas self-esteem was negatively correlated with the use of claimed self-handicaps. Our results support the notion that the use of behavioral self-handicaps may be linked to situation-specific low levels of self-efficacy for performance on the upcoming task. Athletes who use behavioral self-handicaps may take such a risk because they are convinced of an impending performance failure, as evidenced by their lower levels of task self-efficacy. Although behavioral self-handicappers may feel that they have nothing to lose (in terms of their performance) by using a behavioral self-handicap, they can still protect their self- and public-images by using such a strategy.

Our findings were consistent with previous research which showed that individuals who anticipated an upcoming failure intended to use a behavioral self-handicap (Pyszczynski \& Greenberg, 1983). Importantly, our findings extended this work by showing that athletes with self-doubts will actually use a behavioral self-handicap (i.e., time spent warming up). With regard to the use of claimed self-handicaps, our results supported Martin and Brawley's (2002) findings, as claimed self-handicaps were significantly negatively correlated with self-esteem Athletes who use claimed self-handicaps seem to suffer from more general self-doubts (i.e., low self-esteem). As predicted, they may prefer to use claimed self-handicaps, and not behavioral self-handicaps, because they hope to succeed in spite of their low self-esteem.

The second purpose was to compare the relationships between behavioral and claimed self-handicaps and athletic performance. The results provided partial support for our hypotheses. Specifically, performance on a basketball task was negatively related to behavioral self- 
1 handicapping, but was not related to claimed self-handicapping. Our findings are consistent with

2 those of Elliot and colleagues (2006) who showed that reduced preparatory effort (i.e., a

3 behavioral self-handicap) is linked with poorer performance. However, contrary to previous

4 research (Leary \& Shepperd, 1986; Ryska et al., 1998), our results did not show that claimed self-

5 handicaps improve performance. In these previous studies, it was suggested that self-handicaps

6 improve performance by reducing performance pressure; perhaps in the present study, because

7 social evaluative pressures were made so salient, the reduction of the anxiety from claimed self-

8 handicaps was not sufficient to enhance performance.

9 Our results make an important contribution to theory by providing the first sports-based

10 evidence of the conceptual distinction between self-handicapping behaviors and claims. We have

11 shown that the two strategies are indeed related to different factors and can have different

12 consequences for performance. From an applied perspective, given that self-efficacy was related

13 to behavioral self-handicapping which was, in turn, associated with poorer performance, our

14 results suggest that coaches, sport psychologists, and other interventionists should endeavour to

15 promote strong self-efficacy among their athletes. Not only is self-efficacy important for success

16 (e.g., Bandura, 1997) but as the observed correlation between self-efficacy and warm-up time

17 indicate, self-efficacy is also important for deterring the use of harmful behavioral self-handicaps.

18 Despite these contributions, a couple of limitations warrant mention. First, given the relatively

19 small number of participants with a similar level of ability, the generalizability of our study

20 findings are limited. Second, the measure of behavioral self-handicapping could be confounded

21 by factors such as over-confidence or weak motivation. Future research would benefit from

22 testing these hypotheses with a larger, more heterogeneous sample, and controlling for potential

23 confounds of behavioral self-handicapping. 


\section{References}

Bandura, A. (1986). Social foundations of thought and action: A social cognitive theory. Englewood Cliffs, NJ: Prentice-Hall.

Bandura, A. (1997). Self-efficacy: The exercise of control. New York: Freeman.

Bandura, A., \& Adams, N. E. (1977). Analysis of self-efficacy theory of behavioral change. Cognitive Therapy and Research, 1, 287-310.

Berglas, S., \& Jones, E. E. (1978). Drug choice as a self-handicapping strategy in response to non contingent success. Journal of Personality and Social Psychology, 36, 405-417.

Carron, A. V., Prapavessis, H., \& Grove, J. R. (1994). Group effects and self-handicapping. Journal of Sport and Exercise Psychology, 16, 246-257.

Coudevylle, G., Famose, J-P., Martin Ginis, K., \& Gernigon, C. (2008). Les stratégies d'autohandicap : Caractéristiques et déterminants. Illustrations dans le domaine des activités physiques et sportives. Manuscript under review.

Elliot, A. J., Cury, F., Fryer, J. W., \& Huguet, P. (2006). Achievement goals, self-handicapping, and performance attainment: A mediational analysis. Journal of Sport \& Exercise Psychology, 28, 344-361.

Harris, R. N., \& Snyder, C. R. (1986). The role of uncertain self-esteem in self-handicapping. Journal of Personality and Social Psychology, 51, 451-458.

Hirt, E. R., Deppe, R. K., \& Gordon, L. J. (1991). Self-reported versus behavioral selfhandicapping: Empirical evidence for a theoretical distinction. Journal of Personality and Social Psychology, 61, 981-991.

Kuczka, K. K., \& Treasure, D. C. (2005). Self-handicapping in competitive sport: Influence of the motivational climate, self-efficacy, and perceived importance. Psychology of Sport and Exercise, 6, 539-550. 
Leary, M. R., \& Shepperd, J. A. (1986). Behavioral self-handicapping vs. self-reported handicaps: A conceptual note. Journal of Personality and Social Psychology, 51, 12651268.

Martin, K. A., \& Brawley, L. R. (2002). Self-handicapping in physical achievement settings: The contributions of self-esteem and self-efficacy. Self and Identity, 1, 337-351.

Prapavessis, H., Grove, J. R., \& Eklund, R. C. (2004). Self-presentational issues in competition and sport. Journal of Applied Sport Psychology, 16, 19-40.

Pyszczynski, T., \& Greenberg, J. (1983). Determinants of reduction of intended effort as a strategy for coping with anticipated failure. Journal of Research in Personality, 17, 412422.

Ryska, T. A. (2002). Effects of situational self-handicapping and state self-confidence on the physical performance of young participants. The Psychological Record, 52, 461-478.

Ryska, T. A., Yin, Z. N., \& Cooley, D. (1998). Effects of trait and situational self-handicapping on competitive anxiety among athletes. Current Psychology, 17, 48-56.

Thompson, T., \& Richardson, A. (2001). Self-handicapping status, claimed self-handicaps and reduced practice effort following success and failure feedback. The British Journal Educational Psychology, 71, 151-170.

Tice, D. M. (1991). Esteem protection or enhancement? Self-handicapping motives and attributions differ by trait self-esteem. Journal of Personality and Social Psychology, 60, $711-725$.

Vallières, E., \& Vallerand, R. J. (1990). Traduction et validation canadienne-française de l'échelle de l'estime de soi de Rosenberg. International Journal of Psychology, 25, 305316. 
